\title{
STABILIZED MUD MORTAR
}

\author{
Rashmi $\mathbf{S}^{\mathbf{1}}$, Jagadish K $\mathbf{S}^{2}$, Nethravathi $\mathbf{S}^{\mathbf{3}}$ \\ ${ }^{I} P G$ Student, Dept. of Civil Engineering, R V C E, Bangalore, India \\ ${ }^{2}$ Professor, Dept. of Civil Engineering, $R$ V C E, Bangalore, India \\ ${ }^{3}$ Assistant Professor, Dept. of Civil Engineering, $R$ V C E, Bangalore, India
}

\begin{abstract}
Masonry mortar is a homogenous mixture comprising of fine aggregates, binding material and water. In the present scenario, where the supply of sand is falling short of meeting the demand, it becomes imperative to finding an alternative. Mud mortar was commonly used for low rise masonry buildings in the past. When the soil used for the mortar contains clay, problems like volume instability due to its high affinity towards water. To negate this effect, stabilization of the mortar is necessary. Cement and lime are used as binders individually and in combination. The paper focuses on an experimental study to understand the various characteristics of stabilized mud mortars. Workability and strength of 12 different combinations of stabilized mud mortars have been examined. Flow table tests were conducted to quantify the workability of the mortars. It was observed that the water requirement of the mortar for attaining $100 \%$ flow increases with the increase in the clay fraction of the mortar mix. In the present work, the viability of replacing sand partially or fully with locally available red soil and brick dust is studied. The mortar with the alternative fine aggregates, mixed with different combinations of binding materials i.e., cement and lime was tested for 28 days compressive strength. The mortar with 50\% replacement of sand and $12 \%$ cement has compressive strength in the range of $4.25 \mathrm{MPa}$ which is acceptable as per the IS code specification, the minimum strength requirement of mortar to be $3 \mathrm{MPa}$. Therefore, the use of stabilized mud mortar in construction would prove to be sustainable as well economical.
\end{abstract}

Keywords: Mud mortar, stabilization, cement and lime, compressive strength

\section{INTRODUCTION}

In the midst of rising trend of reinforced concrete structures, especially for high end projects where industries hold no regard for the sky rocketing prices of raw material, labour and transportation, the common man can only dream of building a decent shelter for himself. Therefore, a need arises to find feasible alternative building materials which is not only locally available and economical, but is also a way towards sustainable development.

In order to develop new technologies, methods etc, it is always wise to look back at history so as to know and learn the simpler yet smarter ways of past. From the Stone Age to Iron Age, earth has been the main part of any construction in its different forms. It should be noted that mud was used for mortar and more than often as the material of which entire buildings were made. Local availability of mud makes its use advantageous, and ease of processing makes it the most energy efficient building material. Mud has been extensively used for building construction in India and elsewhere since time immemorial. Mud wall construction is common even now in the rural parts of India. Approximately 55\% of all India homes still use raw earth for walls. From history it is found that mud is a tested material extensively. Some of the main advantages of earth are: availability in large quantities, low price, easy to use and good fire resistance etc. It has some disadvantages, like its durability, which can be affected by the action of the natural agents like rain, wind and others, but being a cost effective and energy efficient material, it is very reliable for low rise buildings in general and low cost buildings in particular. Researchers have found ways to enhance earth's durability and quality as a construction material for low-cost buildings. Stabilization is one such technique used to overcome the drawbacks of pure mud construction [1].

Mud mortar is prepared by mixing soil with water until it is workable i.e., until the mortar is in the plastic state. Mud mortar sets quickly on drying hence it does not require an elaborate curing process. Mud mortars are still being used in many parts of the world. Different types of soils can be used to prepare the mortar. Depending upon the soil type, the properties of the mortar varies. Hence to use the locally available soil in mortar and attain optimum use of it, particular preparation techniques and construction practices including addition of stabilizers are followed. Mud mortars are used in the construction of arches, vaults, masonry walls, arches and domes etc. they are particularly advantageous as no shuttering is required during construction. They function as a waterproofing coat and also improve the appearance of a building. External renders are liable to wear away at a rate depending on the harshness of the exposure conditions. They require regular maintenance and periodic repair, although if well-protected they can last a very long time indeed. 


\subsection{Clay}

Generally, the presence of clay in moderate amounts in a soil is desirable. Since clay has cohesive nature, it imparts plasticity to the soil when under moist conditions. Plasticity is due to the thin film of absorbed water which adheres strongly to the clay layers thus linking the particles together. Thus, the clay minerals act as natural binding agents for the cohesionless granular fractions of a soil (gravel, sand, and silt). Although, due to certain drawbacks are of clay are the facts that it has a high affinity towards water. Clayey soils swell in presence of water and shrinks in the absence of it. If the clay mineral is montmorillonite, this kind of swelling and shrinking is more prominent. Such volume instability is not highly undesirable in mortars. Therefore, soils which have clay content below $30 \%$ can be stabilized using cement and soils which clay content above $30 \%$ can be stabilized using lime.

\subsection{Lime}

Lime has the capacity to stabilize clayey soils through pozzolanic reaction. This reaction produces stable calcium silicate hydrates and calcium aluminate hydrates as the calcium from the lime reacts with the aluminates and silicates solubilized from the clay. The modification occurs because hydrated lime supplies calcium cations that replace the cations present on the surface of the clay particles. The process is promoted by the high $\mathrm{pH}$ environment of the lime-water system. The full-term pozzolanic reaction can continue for a very long period of time, even decades as long as enough lime is present and the $\mathrm{pH}$ remains high (above 10). As a result, lime treatment can produce high and long-lasting strength gains, improvements in shear strength and durability in severe environmental conditions.

\subsection{Brick Dust}

Brick dust is obtained from construction and demolition waste. Brick dust finely ground into a powder can bring about a pozzolanic reaction when combined with lime given that they are composed of a type of clay that has a sufficient amount of soluble silica and alumina [2]. Soluble silica and alumina react with calcium hydroxide and water to form a variety of calcium silicate hydrates, or C-S-H gel, that are responsible for the increase in the strength of the mortar.

\section{EARLIER INVESTIGATIONS}

Much research has been done on the characteristics of mortars. Most of these studies focused on cement mortar, lime mortar, cement-soil mortar, etc. There are no dedicated studies on partial and complete replacement of sand and the optimum binders required. There have been many studies that focus on cement soil mortars which help in deducing what parameters are to be applied in the present study. Results of some earlier researches on mortars are highlighted below. Walker and Stace [3] studied the properties of some cement stabilized earth blocks and mortars. The effect of soil properties and cement content on the mortar was studied. They found that increase in clay fraction decreased the compressive strength while increase in cement content increased the strength of the mortar. Venkatarama Reddy and Ajay Gupta [4] based one of their research works purely on finding the characteristics of cement-soil mortars. They carried out tests on cement-soil mortar, cement mortars and cement-lime mortars and compared the results. They used red loamy soil which contained $16 \%$ clay fraction containing kaolonite clay mineral. The trials were made on 4 different clay content percentages and three different percentages of cement. When the results were compared, it was found that composite mortars attain more flow values compared to pure cement mortars. Flow values signify the workability of the mortar. A linear relationship exists between water cement ratios and flow value of mortars. As the water-cement ratio increases, flow value increases. Very high flow value of $130 \%$ can be achieved for cement soil mortars and cement lime mortars. Venkatarama Reddy and Ajay Gupta [5] worked on determining the strength and elastic properties of stabilized mud block masonry using cement-soil mortars. Their study was focused on finding the properties of masonry built of stabilized mud blocks and cement-soil mortars. The soil used in mortar was same as that used in the blocks i.e., locally available red loamy soil containing $16 \%$ of clay. The clay content in the sample was varied by mixing soil with natural sand. For the same workability, when the masonry was tested, it was found that the compressive strength of the masonry was $15-20 \%$ higher in the masonry with cement-soil mortar and cement-lime mortar than the masonry with pure cement mortar. The compressive strength and modulus of cement-soil mortar depends on cement content and clay fraction. The study demonstrates that cement-soil mortar, which is cheaper than conventional mortars, can be beneficially used for SMB masonry. Laura Rampezzi and Roberto Bugini [6] studied the behavior of brick and mortar interface. The samples were taken from the Basilica di San Lorenzo in Milan. They found that thin layer of light colour was formed which was the reason for the pozzolanic reactions. This layer mostly consisted of calcium and silica. Through this study they deducted that the calcium hydroxide in the mortar and the silica in the brick dust reacted to give silicates thus forming a bond between lime and brick dust which strengthens the mortar. Venkatarama Reddy et.al. [7] explored the enhancing bond strength and characteristics of soil-cement block masonry. The masonry was tested with two types of mortar namely cement-soil mortar (CSM) and cement lime mortar (CLM) with flow value of $100 \%$ (Gupta 2003). Mortar compressive strength was determined from $7 \mathrm{~cm}$ cubes. A 28 day compressive strength is 3.45 and $2.93 \mathrm{MPa}$ for CSM and CLM mortars, respectively.

Thus, it is clear that using cement-soil mortars is more beneficiary than conventional cement mortars. Though studies have been conducted on mortars in which sand has been 
partially replaced, it is clear that an attempt has not been made to determine if soil can completely replace sand. If so, then what amount of binder should be added to it. Also, the possibility of replacing sand by soil as well as a pozzolanic material like brick dust in a mortar mix has been explored in the present work.

\section{EXPERIMENTAL PROGRAMME}

The present work focuses on characterizing the properties of stabilized mud mortars. The characteristics like workability and compressive strength are determined for different proportions of mortars. Mix proportions are given in table 1 . The mortar mix proportions in this study are based on weight.

Table -1: Mix proportions

\begin{tabular}{|l|l|l|l|l|l|}
\hline \multirow{2}{*}{$\begin{array}{l}\text { Morta } \\
\text { design } \\
\text { ation }\end{array}$} & \multicolumn{4}{|l}{ Mortar proportion } \\
\cline { 2 - 6 } & Soil & Sand & $\begin{array}{l}\text { Brick } \\
\text { dust }\end{array}$ & $\begin{array}{l}\text { Cemen } \\
\mathrm{t}\end{array}$ & Lime \\
\hline M2 & $100 \%$ & - & - & $12 \%$ & - \\
\hline M3 & $100 \%$ & - & - & $10 \%$ & $5 \%$ \\
\hline M4 & $100 \%$ & - & - & $5 \%$ & $10 \%$ \\
\hline M5 & $50 \%$ & $50 \%$ & - & $12 \%$ & - \\
\hline M6 & $50 \%$ & $50 \%$ & - & $10 \%$ & $5 \%$ \\
\hline M7 & $50 \%$ & $50 \%$ & - & $5 \%$ & $10 \%$ \\
\hline M8 & $50 \%$ & $50 \%$ & - & - & $10 \%$ \\
\hline M9 & $50 \%$ & $25 \%$ & $25 \%$ & $12 \%$ & - \\
\hline M10 & $50 \%$ & $25 \%$ & $25 \%$ & $10 \%$ & $5 \%$ \\
\hline M11 & $50 \%$ & $25 \%$ & $25 \%$ & $5 \%$ & $10 \%$ \\
\hline M12 & $50 \%$ & $25 \%$ & $25 \%$ & - & $10 \%$ \\
\hline
\end{tabular}

\subsection{Materials Used}

For the study, locally available red soil is used. This natural soil has $20 \%$ clay fraction and liquid limit $37.5 \%$. The clay content is varied by diluting it with natural sand and brick dust. The brick dust is obtained by manually ramming construction and demolition waste. The cement used is of OPC 53 grade. The lime bought in the form of limestones, is slaked and used.

\section{TESTING PROCEDURE}

\subsection{Determination of Workability through Flow Tests}

Workability of the mortar should be such that it can be spread easily and adheres well with the masonry unit. Composition of the mix and water cement ratios are two major factors that affect workability. In the present study, the workability characters are measured by conducting flow table tests. Here, the flow is maintained at $100 \%$ and the water cement ratio is determined.

\subsection{Compressive Strength of Mortar}

The compressive strength of mortar was determined by testing $70 \mathrm{~mm}$ size cube specimens. The specifications of I.S. 2250 code are followed. The mould greased and uniformly mixed mortar is then filled in 3 layers. Each layer is tamped 25 times using a standard tamping rod. The mortar cubes are demoulded after 24 hours and cured. After 28 days of curing, the specimens are tested in compression testing machine in saturated conditions.

\section{RESULTS AND DISCUSSIONS}

For $100 \%$ flow, the water content by weight mortar mix and 28 days compressive strength is as given in table 2 . It is observed that when the water requirement of the mortar increases with the increase in clay fraction. The compressive strength of mortar mix with $10 \%$ clay fraction and $12 \%$ cement has the highest strength. The mortars with $20 \%$ clay fraction (M1 and M2) have compressive strength nearer to $3 \mathrm{MPa}$. The mortar mixes with more clay and lime content are expected to gain strength over a period of time. They may be used as low strength mortar.

Table -2: Water content for $100 \%$ flow and 28 Compressive strength

\begin{tabular}{|l|l|l|}
\hline $\begin{array}{l}\text { Mortar } \\
\text { designation }\end{array}$ & $\begin{array}{l}\text { Water content } \\
(\%)\end{array}$ & $\begin{array}{l}28 \text { days } \\
\text { compressive } \\
\text { strength } \\
\text { (MPa) }\end{array}$ \\
\hline M1 & 35.03 & 2.42 \\
\hline M2 & 33.15 & 2.64 \\
\hline M3 & 37.44 & 1.26 \\
\hline M4 & 35 & 1.02 \\
\hline M5 & 20.22 & 4.25 \\
\hline M6 & 23.94 & 3.40 \\
\hline M7 & 29.68 & 1.24 \\
\hline M8 & 27.95 & 0.66 \\
\hline M9 & 24.78 & 3.49 \\
\hline M10 & 29.65 & 3.17 \\
\hline M11 & 32.05 & 1.72 \\
\hline M12 & 30.38 & 0.98 \\
\hline & & \\
\hline
\end{tabular}




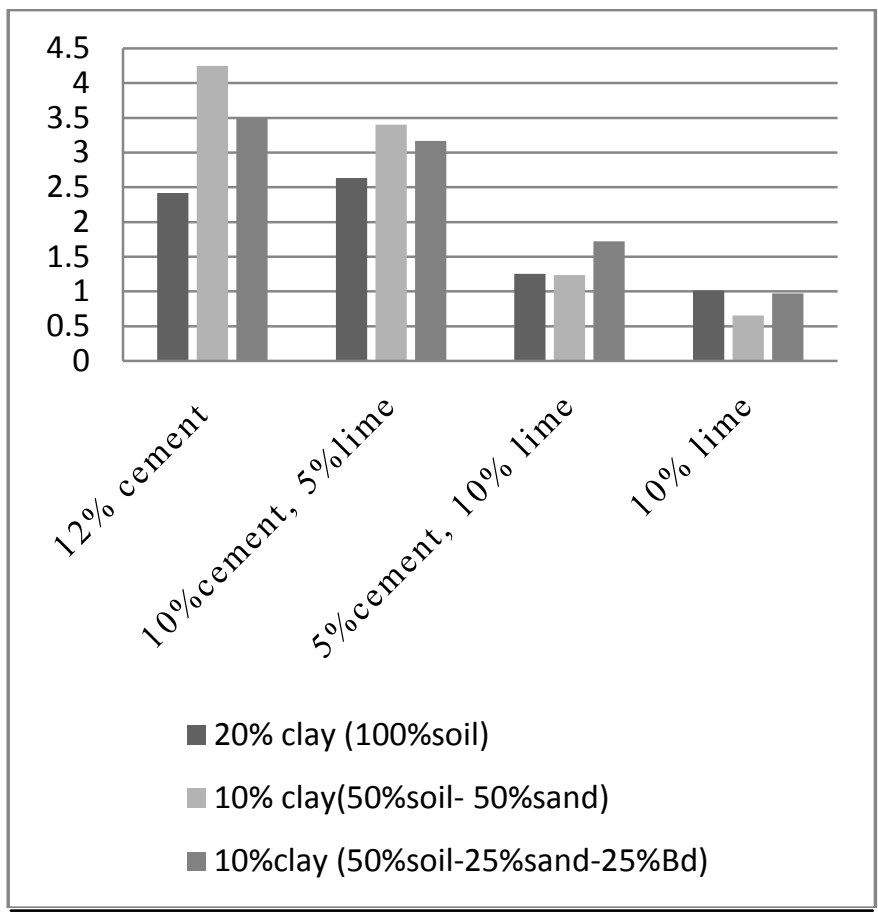

Chart -1: 28 days compressive strength

When lime is added, it is noticed that the strength increases with increase in clay fraction. The comparison of the compressive strengths of the mortar mixes is shown in chart 1.

\section{CONCLUSIONS}

It is evident from the studies that partial replacement of sand is viable as a maximum strength of $4.25 \mathrm{MPa}$ is obtained which clearly exceeds the limit (3MPa) established by I.S. 2250 code. The mortars containing lime may be used as low strength mortars. Therefore, the construction can be made economical as well as eco-friendly.

\section{REFERENCES}

[1]. K.S. Jagadish, Building with Stabilized Mud, IK International Publishing House Pvt. Ltd, New Delhi, 2007.

[2]. Rogers, Sara B, Evaluation and Testing of Brick Dust as a Pozzolanic Additive to Lime Mortars for Architectural Conservation. (MastersThesis). University of Pennsylvania, Philadelphia, PA 2011.

[3]. Walker P and Stace, T., Properties of some cement stabilized compressed earth blocks and mortars, Mater.Struct.30, pp545-551, Nov 1997

[4]. B. V. Venkatarama Reddy and Ajay Gupta, Characteristics of Cement-Soil Mortars, Materials and Structures, Vol.38, pp 639-650, July 2005.

[5]. B. V. Venkatarama Reddy and Ajay Gupta, Strength and Elastic Properties of Stabilized Mud Block Using Cement-Soil Mortars, Journal of Materials in Civil Engineering, Vol.18, No.3, pp 472-476, June 2006.
[6]. Laura Rampezzi and Roberto Bugini, St. Lorenzo basilica in Milan: integral approach to characterization of historical mortars, e-preservation science, Vol.3, pp 21-26, July 2006.

[7]. B.V. Venkatarama, Reddy, Richardson Lal and K. S. Nanjunda Rao, Enhancing Bond Strength and Characteristics of Soil Cement Block Masonry, Journal of Materials in Civil Engineering, Vol.19, No.2, pp 164-172, 2007.

[8]. IS:2250, 'Indian standard code of practice for preparation and use of masonry mortars' bureau of Indian standards, New Delhi, India, 1981 